\title{
Mechanical and physical control in apple orchards as preventative fungal disease management
}

\author{
Holb, I.J. \\ University of Debrecen, Faculty of Agriculture, Institute of Horticulture, \\ 138. Böszörményi str., Debrecen, H-4032,Hungary (holb@agr.unideb.hu)
}

\begin{abstract}
Summary: In this minreview, mechanical and physical control against apple fungal diseases among non-chemical control approaches were summarized. This overview listed five groups of mechanical and physical control methods: pruning, removal of inoculum sources, shredding of leaf litter, burying of inoculum sources and flaming of leaf litter. These methods were shown to reduce succesfully infection potential of inoculum sources in orchards and these non-chemical control measures are one of the most essential approaches for preventative fungal disease management. However, most of these methods are not widely spread in the apple-growing practice due to relatively low control efficacy, medium to high labour costs and/or time limits during the season.
\end{abstract}

Keywords: Malus $x$ domestica Bork., mechanical and physical control, apple fungal diseases, pruning, removal and shredding of leaf litter, burying and flaming of leaf litter

\section{Introduction}

In apple production, the key fungal disease are apple scab (Venturia ineaqualis), apple powdery mildew (Podosphaera leucotricha), European canker (Nectria [Neonectria] galligena), brown rot (Monilinia spp.) and the disease complex of flyspeck and sooty blotch in preharvest disease management of apple (Holb, 2009). Among control methods one of the most environmentally freindly control approach is the mechanical and physical control against apple fungal diseases among non-chemical control approaches. The most known methods in mechanical and physical control methods are pruning, removal of inoculum sources, shredding of leaf litter, burying of inoculum sources and flaming of leaf litter
(Table 1). These methods are known to reduce/eliminate inoculum sources of fungal diseases in apple orchards. The aim of this minireview was to summarize mechanical and physical control methods against the above mentioned six fungal diseases in preharvest disease management.

\section{Pruning}

Pruning of trees can reduce several diseases of apple by the removal of diseased plant parts. Dormant pruning reduces overwintered conidial inoculum of apple scab (Holb et al., 2004; 2005). The authors showed if autumn scab incidence on leaves was above $40 \%$, the upper two-third of

Table 1. Some reviewed aspects of mechanical and physical control approaches used against scab, powdery mildew, European canker, brown rot, flyspeck and sooty blotch in preharvest disease management of apple

\begin{tabular}{|c|c|c|c|c|c|}
\hline \multirow{2}{*}{$\begin{array}{c}\text { Mechanical and physical } \\
\text { control approaches }\end{array}$} & \multicolumn{5}{|c|}{ Fungal disease } \\
\hline & Apple scab & $\begin{array}{l}\text { Apple powdery } \\
\text { mildew }\end{array}$ & European canker & Brown rot & $\begin{array}{c}\text { Flyspeck and sooty } \\
\text { blotch }\end{array}$ \\
\hline Pruning & $\begin{array}{l}\text { woody-shoot, bud, shoot, } \\
\text { leaf, fruit }\end{array}$ & $\begin{array}{l}\text { woody-shoot, shoot, } \\
\text { bud }\end{array}$ & $\begin{array}{l}\text { infested twig, leaf } \\
\text { scars, shoot }\end{array}$ & $\begin{array}{l}\text { mummified fruit, } \\
\text { infested fruit }\end{array}$ & infested fruit \\
\hline Removal of alternate host & $\begin{array}{l}\text { wild apple, hawthorn, } \\
\text { mountain ash, firethorn, } \\
\text { locquat }\end{array}$ & - & - & rosaceous hosts & blackberry \\
\hline Removal of crop debris & $\begin{array}{l}\text { fallen leaf; against primary } \\
\text { inoculum }\end{array}$ & - & - & $\begin{array}{l}\text { dropped fruit; } \\
\text { clustered fruit against } \\
\text { asexual inoculum }\end{array}$ & $\begin{array}{l}\text { clustered fruit; against } \\
\text { asexual inoculum }\end{array}$ \\
\hline Shredding of leaf litter & against primary noculum & - & - & - & - \\
\hline $\begin{array}{l}\text { Burying of inoculum; } \\
\text { flaming of leaf litter }\end{array}$ & against primary inoculum & - & - & - & - \\
\hline
\end{tabular}


terminals may need to be pruned before bud break in order to eliminate overwintered conidia associated with buds (Holb et al., 2005).

Dormant season pruning also reduce primary inoculum of apple powdery mildew. Removal of shoots during winter pruning is a well-knonw control practice (e.g. Csorba, 1962; Hickey and Yoder, 1990; Holb, 2005). Seasonal disease development of powdery mildew can also be reduced by removal of infected shoot not only in dormant bud stage but during the season on unfolded young shoots (e.g. Csorba, 1962; Hickey and Yoder, 1990).

Dormant pruning is one of the major management options against European canker. Removal of infested twigs reduces the spread of the disease but pruning cuts can be important sites for a new infection (Kennel, 1963; Swinburne, 1971). High inoculum dose and young pruning wounds resulted in higher risk of infection ( $\mathrm{Xu}$ and Butt, 1996). Therefore, all cuts needs to be protected with for instance fungicide treatment, wound-treatment with an effective canker paint (Cooke, 1999).

Pruning of mummified fruits is also an effective control practice to reduce inoculum sources of brown rot (Wormald, 1954; Leeuwen et al., 2002). During the season, all infected fruit should also be removed for effective brown rot management (Holb and Scherm, 2007).

\section{Removal of inoculum sources}

Removal of inocuéum sources are mostly done by removal of infected crop debris such as infected leaves, dropped fruit and clustered fruit.

For instance, $V$. inaequalis overwinters on leaf debris and many studes demonstrated that fallen leaf removal reduced the primary inoculum source of apple scab in the following spring (e.g. Louw, 1948; Holb, 2006, 2007; Gomez et al., 2007). These studies demonstrated that leaf removal can reduce ascospore production by 56 to $79 \%$ and leaf scab incidence in spring by $18-57 \%$. Fallen leaf removal can be performed in combination with other orchard management activities (Holb, 2007).

Removal of dropped fruit is also an effective control method against Monilinia fructigena (Holb and Scherm, 2007). Authors demonstrated that the early summer fruit drop serves as a bridge between inoculum of overwintered fruit mummies in the spring and the first infected fruit in the tree in midsummer. Therefore, removal of these dropped fruits reduces disease incidence on fruit in the tree in organic orchards.

Removal of clustered fruit reduces sooty blotch and flyspeck, because clustered fruit provide a more favourable microclimate for disease development than single fruit (Sutton, 1990b). Clustered patterns of fruit also increase brown rot of apple fruit due to fruit to fruit contact and/or insect damage among the members of the cluster (Leeuwen et al., 2000; Xu et al., 2001, Holb and Scherm, 2008).
Removal of infected branches and stems during the season also reduces inoculum sources of $N$. galligena (Scheer, 1980).

\section{Shredding of leaf litter}

Leaf shredding can reduce primary scab infection from 45 to $85 \%$ and therefore a common sanitation practice in most orchards (Sutton et al., 2000; Vincent et al., 2004; Holb, 2007, Holb and Kunz, 2016). Leaf shredding or fallen leaf removal should be combined with other non-chemical control methods such biological control and disease resistant cultivars in order to increase efficacy (Holb and Kunz, 2016).

\section{Burying of inoculum sources}

Burying can be a used succesfully if leaf removal/ shredding can be difficult to perform. Ploughing and disc cultivation are suggested for this purpose (Louw, 1948; Holb, 2007), however, efficacy of disc cultivation is only 50$58 \%$. Therefore, Holb (2007) indicated that efficacy of disc cultivation needs to increase by combining it with other nonchemical control options.

\section{Flaming of leaf litter}

Flaming is mainly used against weeds in orchards though it has reducing efficacy on overwintering inoculum sources of V. inaequalis in fallen leaf litter (MacHardy, 1996; Anderson, 2007). Flaming is not burning the aim is causing cells rupture of the pathogens. Leaf litter on the orchard floor should be heated at a minimum of $70{ }^{\circ} \mathrm{C}$; otherwise, it does not have enough cell rupture effect on $V$. inaequalis ascocarps. Flaming is costly which is two to four times higher than other sanitation or chemical control methods.

\section{Conclusions}

Mechanical and physical control methods are one of the most basic approaches for reducing inoculum sources in apple orchards, but most of these methods are not widely spread in the apple growing practice due to their relatively low efficacy, meidum to high labour costs and/or time limits during the season. Integration of mechanical and physical control methods with other non-chemical control methods can effectively increase disease reduction efficacy and their use in commercial orchards.

\section{Acknowledgements}

This research was supported partly by a grant of the Hungarian Scientific Research Fund (OTKA K108333). 


\section{References}

Anderson R.L. (2007) Managing weeds with a dualistic approach of prevention and control. A review, Agron. Sustain. Dev. 27, 1318. DOI: 10.1051/agro:2006027

Cooke L.R. (1999) The influence of fungicide sprays on infection of apple cv. Bramley's seedling by Nectria galligena, Eur. J. Plant Pathol. 105, 783-790.

Csorba Z. (1962) Az almafa-lisztharmat [Apple Powdery Mildew], Mezőgazdasági Kiadó, Budapest, Hungary.

Gomez C., Brun L., Chauffour D., Le Vallee D. (2007) Effect of leaf litter management on scab development in an organic apple orchard, Agric. Ecosyst. Environ. 118, 249-255.

Hickey K.D., Yoder K.S. (1990) Powdery mildew, in: Jones A.L., Aldwinckle H. S. (Eds.), Compendium of Apple and Pear Diseases, APS, St. Paul, Minnesota, USA, pp. 9-10.

Holb I.J. (2005) Effect of pruning on disease incidence of apple scab and powdery mildew in integrated and organic apple production. Internat. J. Hortic. Sci. 11 (1), 57-61.

Holb I.J. (2006) Effect of six sanitation treatments on leaf decomposition, ascospore production of Venturia inaequalis and scab incidence in integrated and organic apple orchards, Eur. J. Plant Pathol. 115 (3), 293-307.

Holb I.J. (2007) Effect of four non-chemical sanitation treatments on leaf infection by Venturia inaequalis in organic apple orchards, Eur. J. Hort. Sci. 71, 60-65.

Holb I.J. (2009) Fungal disease management in environmentally friendly apple production - a review. Sustainable Agriculture Reviews 2: 219-292. (E. Lichtfouse (ed.), Climate Change, Intercropping, Pest Control and Beneficial Microorganisms, Springer Science, New York)

Holb I.J., Heijne B., Jeger M.J. (2004) Overwintering of conidia of Venturia inaequalis and the contribution to early epidemics of apple scab, Plant Dis. 88, 751-757.

Holb I.J., Heijne B., Jeger M.J. (2005) The widespread occurrence of overwintered conidial inoculum of Venturia inaequalis on shoots and buds in organic and integrated apple orchards across the Netherlands, Eur. J. Plant Pathol. 111, 157-168.

Holb IJ, Kunz S. (2016) Integrated control of apple scab and powdery mildew in an organic apple orchard by combining potassium carbonates with wettable sulfur, pruning and cultivar susceptibility. Plant Dis. 100 (9): 1894-1905.
Holb I.J. Scherm H. (2007) Temporal dynamics of brown rot in different apple management systems and importance of dropped fruit for disease development, Phytopathology 97, 1004-1111.

Holb I.J. Scherm H. (2008) Quantitative relationships between different injury factors and development of brown rot caused by Monilinia fructigena in integrated and organic apple orchards, Phytopathology 98, 79-86.

Kennel W. (1963) Zur pathogenes des obstbaumkrebes (Nectria galligena Bres.) am apfel, Gartenbauwissenschaft 28, 29-64.

Leeuwen van G.C.M., Holb I.J., Jeger M.J. (2002) Factors affecting mummification and sporulation of pome fruit infected by Monilinia fructigena in Dutch orchards, Plant Pathol. 51, 787-793.

Leeuwen van G.C.M., Stein A., Holb I.J., Jeger M.J. (2000) Yield loss in apple caused by Monilinia fructigena (Aderh. \& Ruhl.) Honey, and spatio-temporal dynamics of disease development, Eur. J. Plant Pathol. 106, 519-528.

Louw A.J. (1948) Fusicladium of apples. IV. Can this disease stamped out? Farming Suppl. Afr. J. 5, 28-32.

MacHardy W.E. (1996) Apple Scab, Biology, Epidemiology and Management, APS Press, St. Paul, Minnesota, USA, pp. 545.

Scheer van der H.A.Th. (1980) Kanker bij vruchtbomen (European canker with fruit trees), Mededeling no. 18, Research Station for Fruit Growing, Wilhelminadorp, The Netherlands, pp. 66.

Sutton D.K., MacHardy W.E., Lord W.G. (2000) Effect of leaf shredding or treating apple leaves litter with urea on ascospore dose of Venturia inaequalis and disease buildup, Plant Dis. 84, 1319-1326.

Swinburne T.R. (1971) The seasonal release of spores of Nectria galligena from apple cankers in Northern Ireland, Ann. Appl. Biol. 69, 97-104.

Vincent C., Rancourt B., Carisse O. (2004) Apple leaf shredding as a non-chemical tool to manage apple scab and spotted tentiform leafminer, Agric. Ecosyst. Environ. 104, 595-604.

Wormald H. (1954) The brown rot diseases of fruit trees. Ministry of Agriculture, Fisheries and Food Technical Bulletin 3, 113 pp.

Xu X., Butt D.J. (1996) Tests of fungicides for post-germination activity against Nectria galligena, causal agent of canker and fruit rot of apple, Crop Prot. 15, 513-519.

Xu X.M., Robinson J.D., Berrie A.M., Harris D.C. (2001) Spatio-temporal dynamics of brown rot (Monilinia fructigena) on apple and pear, Plant Pathol. 50, 569-578. 